\title{
O MICROANALIZĂ COMPARATIVĂ A UNUI AN DIN ACTIVITATEA CABINETULUI DE MEDICINA FAMILIEI
}

\section{dr. Bumbuluț Călin, medic primar medicina familiei, instructor formator în medicina familiei, CMI, Satu Mare}

Compararea „productivității” medicilor generalişti în ceea ce priveşte publicarea cercetărilor comparativ cu alte specialități se poate face prin studierea publicațiilor de medicină generală, alte specialități medicale, chirurgicale şi de sănătate publică în baza de date „PubMed”.

Un studiu australian [1] a vizat numărul articolelor publicate de fiecare categorie studiată în perioada 1990-1999, precum şi rata relativă de publicare în rândul generaliştilor şi altor specialitătîi în aceeaşi perioadă. Din totalul articolelor originale publicate de generalişti, 65\% (17/26) au apărut în revista medicilor de familie australieni Australian Family Physician şi 3\% (3/90) în Medical Journal of Australia; alte specialități medicale au avut o proporție de $4 \%$ respectiv $37 \%$. O explicație a concentrării articolelor generaliştilor pe reviste de specialitate de medicină generală este legat de obiectul larg al profilului acestor reviste precum şi de conținutul articolelor de medicină generală, tendința de publicare fiind orientată spre acestea şi nu spre alte reviste medicale cu profil general. Cu alte cuvinte obiectul de studiu în medicina generală este prea vast pentru a-l compara satisfăcător statistic cu alte domenii de specializare sau supraspecializare.

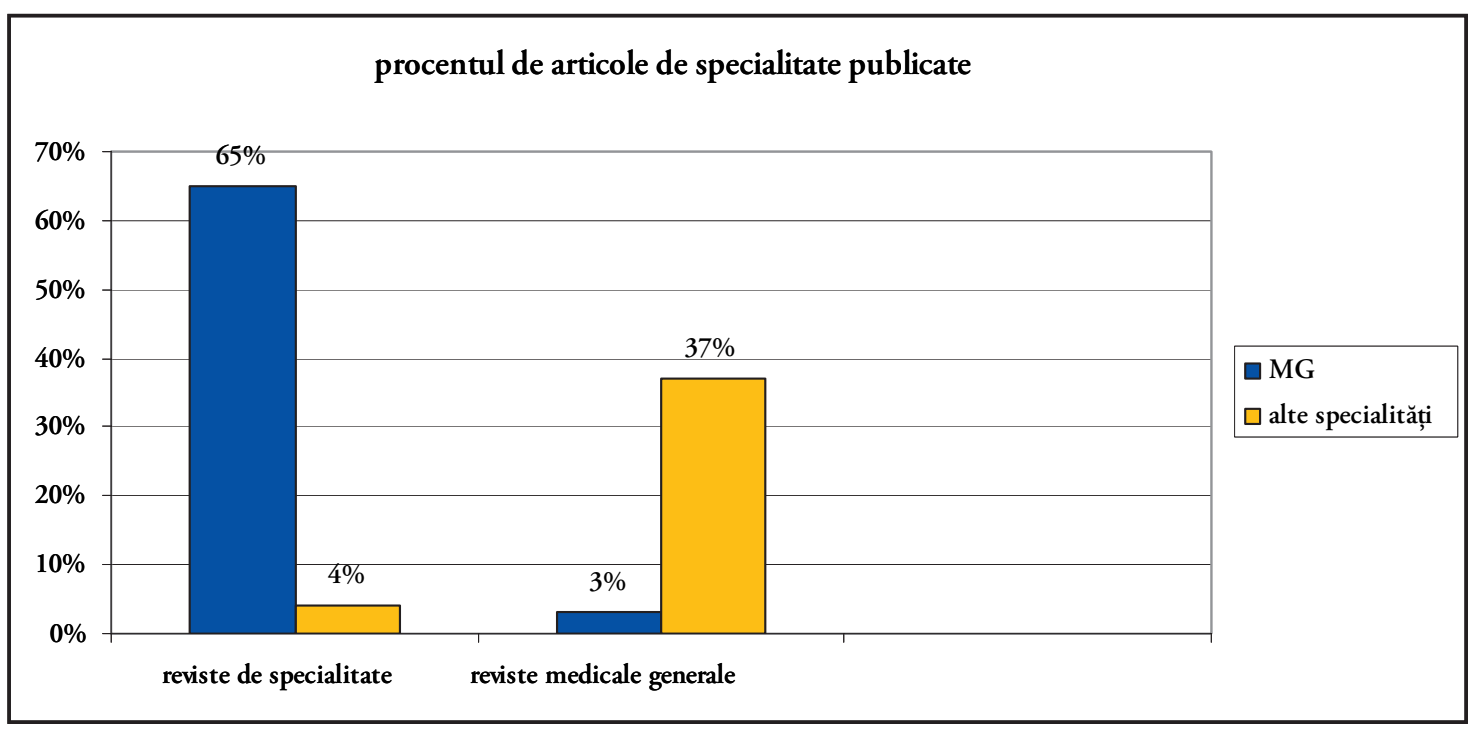

În schimb, în ceea ce priveşte „productivitatea” putem face o comparație obiectivă, chiar dacă numărul medicilor generalişti este mult mai mare decât în alte specialități: în decada 1990-1999 a existat o rată de articole de 1 la 1000 generalişti, pe când ratele corespondente în cadrul altor specialități medicale, chirurgie şi sănătate publică au fost de 105/1000, 61/1000 şi respectiv 148/1000. 


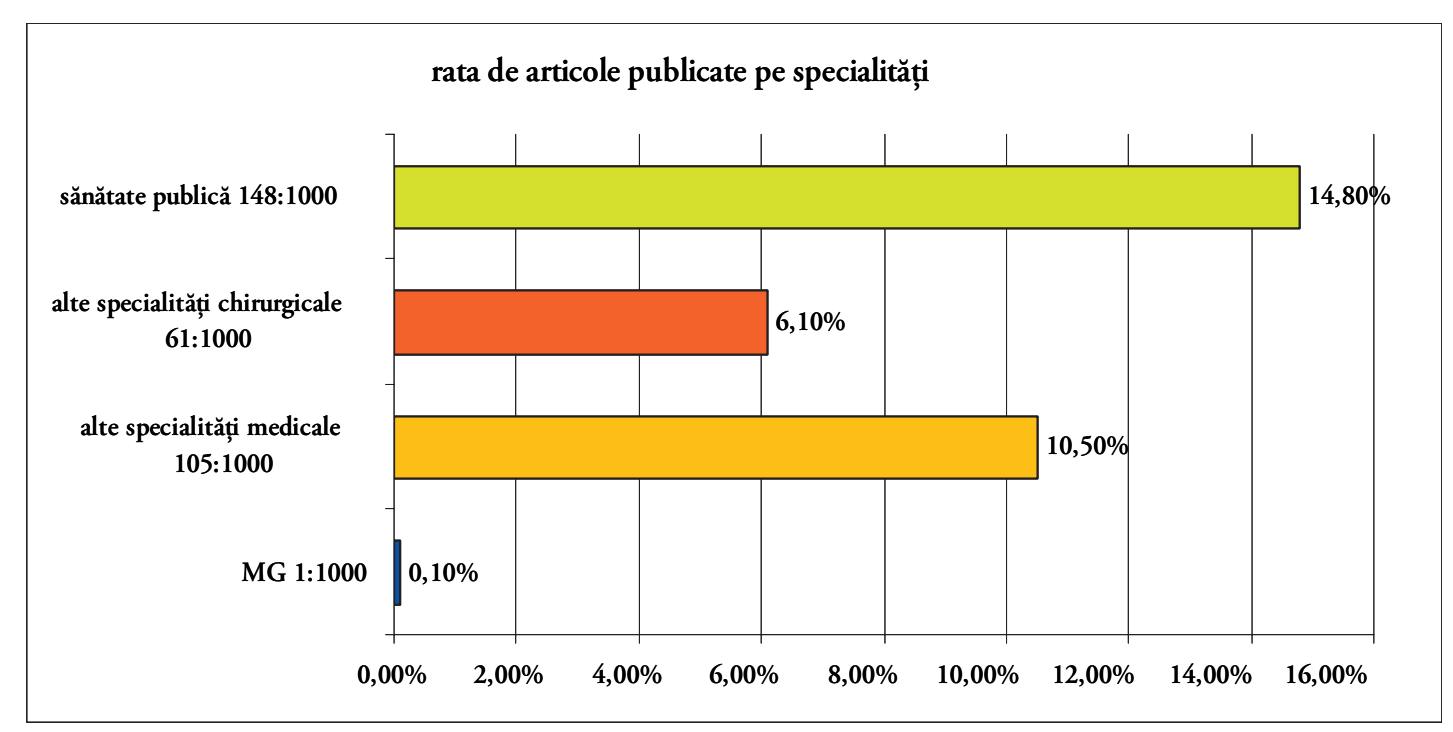

În concluzie există o disproporție considerabilă între nivelul cercetării efectuat în medicina generală comparativ cu alte specialități. Dacă dorim să avem o cercetare eficientă în medicina primară trebuie dezvoltate urgent abilitățile în cercetare, infrastuctura şi cultura care stimulează cercetarea.

Consider că domeniul de cercetare cel mai bun pentru asistența primară este chiar activitatea zilnică; din punct de vedere al sănătății publice, epidemiologiei, statisticii, etc, medicina de familie este o sursă de neînlocuit. Mi-am propus o microanaliză statistică a activitătiii unui cabinet de medicina familiei pe parcursul unui an, cu referiri şi comparaţii acolo unde este necesar pe mai mulți ani.

Material şi metode: analiza datelor colectate la nivelul CMI în anul 2007 prin evidența primară a consultațiilor, prelucrate pe sistem informatic. Evidența consultațiilor şi activității a fost înregistrată în timp real pe parcursul anului şi comparată cu datele publicate de CNAS pe 2004, 2005, 2006, 2007, precum şi un studiu independent din 2007.

Numărul de pacienți înregistrați pe listele Cabinetului Medical Individual la 31 decembrie 2006 era de 2494, iar la 31 decembrie 2007 de 2547 (+53, variație de 2,1\%, mediana 2520). Față de media județului Satu Mare de 1926 asigurați pe medic [2], deviația a fost de $+30,8 \%$, iar față de media națională de 1755 asigurați pe medic [2], deviația a fost de $+43,59 \%$. Într-un studiu independent pe un lot reprezentativ de 1215 medici de familie (10,75\% din totalul MF din 2007), numărul mediu de pacienți pe listă a fost de 1854 [4].

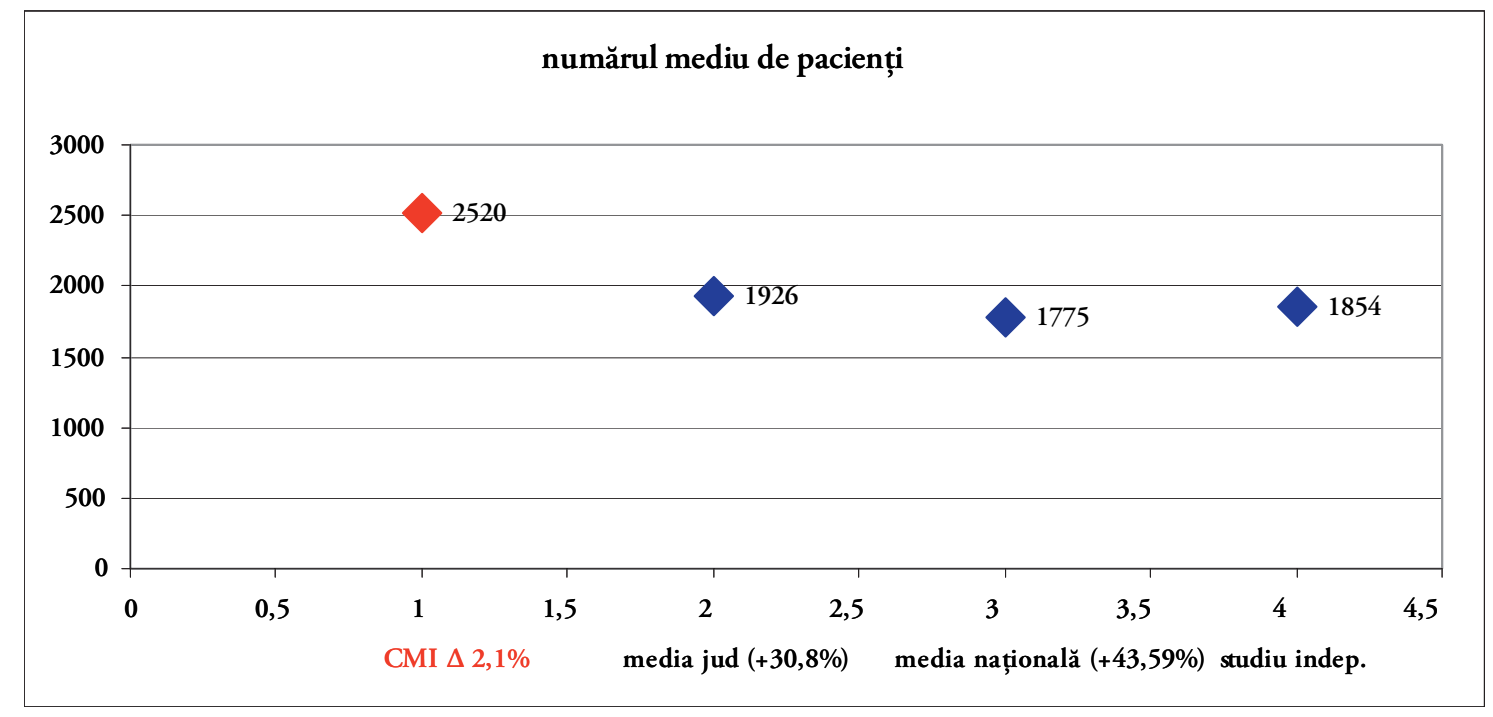


În lista pacienturii raportul între sexe a fost 1,11 în favoarea celui feminin, iar în ceea ce priveşte raportul pe grupe de vârstă din totalul pacienturii, respectiv totalul consultațiilor, în grupa de vârstă de sub 1 an rata consultaţiilor a fost de 3,8 ori mai mare dacât în alte grupe; între 1-14 ani şi peste 14 ani rata consultațiilor a fost apropiată de proporția din totalul populației înscrise.

\begin{tabular}{|l|l|l|l|}
\hline \multicolumn{1}{|c|}{ Total (mediana) } & \multicolumn{1}{|c|}{ sub 1 an } & \multicolumn{1}{c|}{ 1-14 ani } & \multicolumn{1}{c|}{ peste 14 ani } \\
\hline 2520 pacienți $(100 \%)$ & $1,5 \%$ & $29,1 \%$ & $69,4 \%$ \\
\hline 13.065 consultații $(100 \%)$ & $5,7 \%$ & $26,5 \%$ & $67,8 \%$ \\
\hline
\end{tabular}

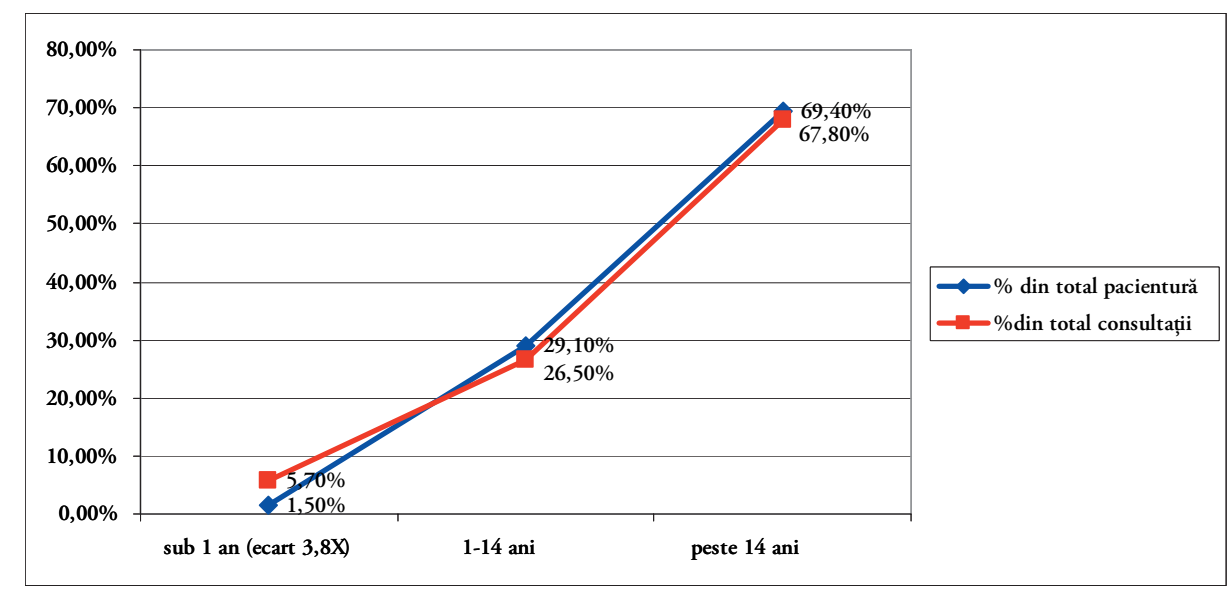

Numărul total de consultații a fost de 13.065 pe an, din care 5359 sex masculin, 7706 sex feminin (f/b 1,44), ceea ce înseamnă cca. 5 consultații/pacient/an. În afara listei proprii de asigurați au mai fost consultați 286 pacienți. Față de media națională de 3980 consultații pe an (total 32.548 .012 în 2004 adică 1,61 consultații/pacient/an, 45.592.285 în 2005 adică 2,26 consultații/pacient/an, 38.534.156 în 2006 adică 1,9 consultații/pacient/an; pentru 2007 nu este furnizat numărul total de consultații din România) [2,3], diferența de $+328 \%$ este de nejustificat dacât dacă datele statistice ale Casei Naționale de Asigurări sunt eronate, sau mai plauzibil aceste date nu cuprind toate tipurile de consultații (cronici, controale cazuri acute, dispensarizări, vaccinări, gravide, controale profilactice, examinări de bilanț, eliberări de acte medicale, etc). Studiul independent mai sus menționat [4] a evidențiat un număr de 3,75 consultații/pacient/an (la o medie de 6972 consultații/an), probabil o cifră mai apropiată de realitate. Diferența de 30-40\% în numărul pacienților față de media națională şi diferența de 328\% în numărul consultațiilor este prea mare pentru a putea fi pusă doar pe seama acesteia.

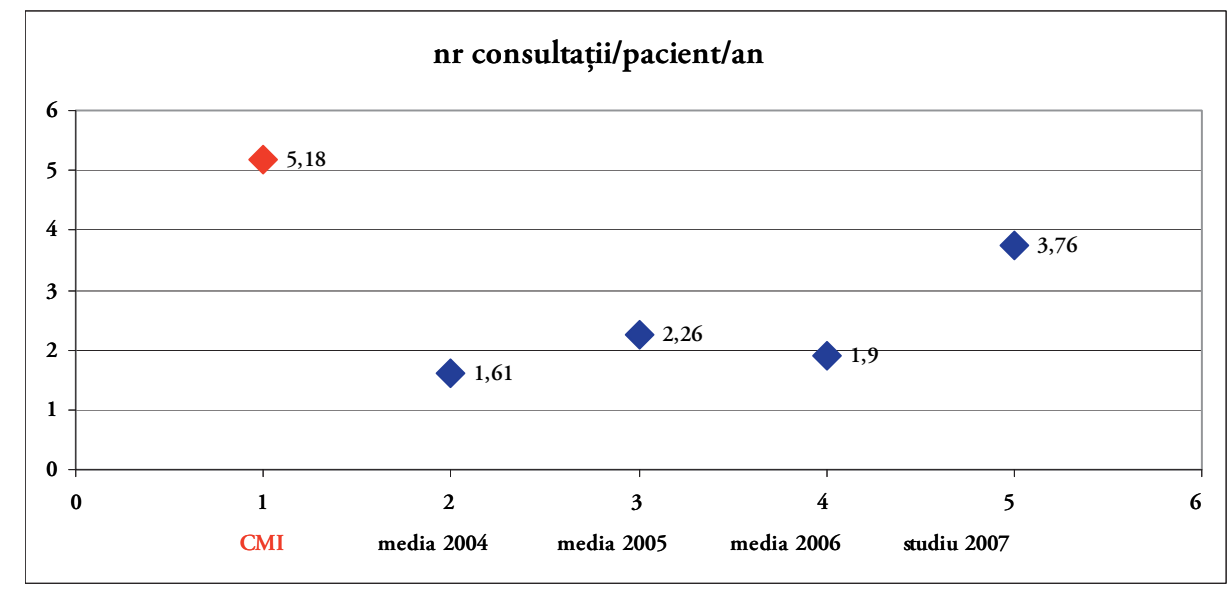

Din analiza datelor se observă concordanța cu statistica națională, cu o morbiditate crescută la sexul masculin sub vârsta de 1 an, sensibil egală între 1 şi 14 ani şi crescută la sexul feminin peste 14 ani: 


\begin{tabular}{|c|c|c|c|c|c|c|c|c|c|c|}
\hline \multicolumn{3}{|c|}{ consultații } & \multicolumn{4}{|c|}{ sex masculin } & \multicolumn{4}{|c|}{ sex feminin } \\
\hline & & & total & $0-14$ ani & $\begin{array}{l}\text { din care sub } \\
1 \text { an }\end{array}$ & $\begin{array}{l}\text { peste } 14 \\
\text { ani }\end{array}$ & total & $\begin{array}{l}0-14 \\
\text { ani }\end{array}$ & $\begin{array}{l}\text { din care } \\
\text { sub } 1 \text { an }\end{array}$ & $\begin{array}{l}\text { peste } 14 \\
\text { ani }\end{array}$ \\
\hline total & $\begin{array}{l}0-14 \\
\text { ani }\end{array}$ & $\begin{array}{l}\text { peste } \\
14 \text { ani }\end{array}$ & \multirow[t]{2}{*}{5359} & \multirow[t]{2}{*}{2161} & \multirow[t]{2}{*}{431} & \multirow[t]{2}{*}{3198} & \multirow[t]{2}{*}{7706} & \multirow[t]{2}{*}{2043} & \multirow[t]{2}{*}{309} & \multirow[t]{2}{*}{5663} \\
\hline 13.065 & 4204 & 8861 & & & & & & & & \\
\hline
\end{tabular}

În ceea ce priveşte numărul de cazuri noi de boală diagnosticate se observă predominanța sexului masculin sub 1 an (B:F 1,47), o proporție relativ egală între sexe între 1-14 ani şi predominanța sexului feminin între 15-64 ani (B:F 0,61) şi peste 65 ani (B:F 0,62). Pe totalul populaţiei depistarea de noi cazuri de boală predomină la sexul feminin (B:F 0,8).

\begin{tabular}{|c|c|c|c|c|c|c|c|c|c|c|}
\hline & \multicolumn{6}{|c|}{ Număr cazuri noi codificate conform rev. 10 OMS pe 992 boli, pe grupe de vârstă şi sex } \\
\cline { 2 - 10 } & Total & \multicolumn{3}{|c|}{ Sub un an } & $1-14$ ani & $15-64$ ani & \multicolumn{2}{c|}{65 ani si peste } \\
\cline { 2 - 10 } & Total & Fem. & Total & Fem. & Total & Fem. & Total & Fem. & Total & Fem. \\
\hline $\begin{array}{c}\text { TOTAL } \\
\text { (001-992) }\end{array}$ & 4712 & 2615 & 264 & 107 & 1958 & 960 & 2218 & 1380 & 272 & 168 \\
\hline
\end{tabular}

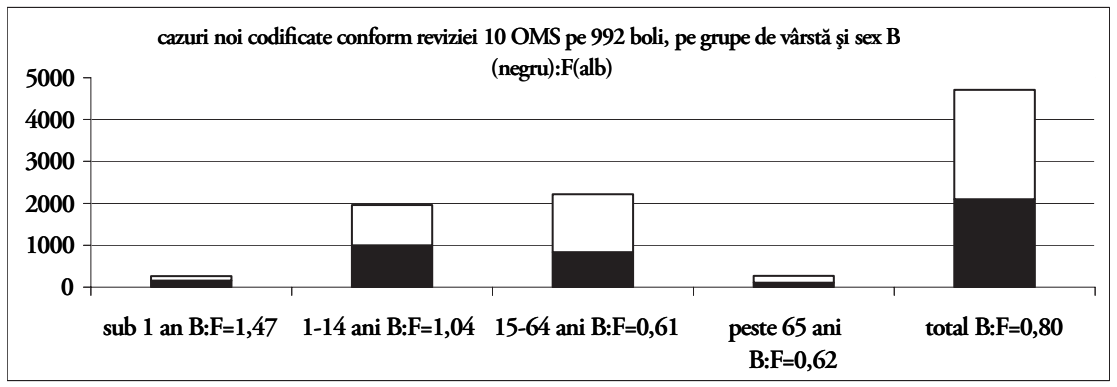

Structura pe tipul de consultație acordată este prezentată în următorul tabel:

\begin{tabular}{|l|l|}
\hline \multicolumn{1}{|c|}{ tipul consultației } & \multicolumn{1}{|c|}{ număr } \\
\hline cazuri acute & $\mathbf{4 7 6 0}$ \\
\hline control caz acut & $\mathbf{9 3 9}$ \\
\hline cazuri cronice & $\mathbf{2 5 2 4}$ \\
\hline dispensarizări (evidență specială) & $\mathbf{2 8 7}$ \\
\hline examene de bilanț de etapă şi anuale (sugari, precum şi copii şi adulți în cadrul PNESS) & $\mathbf{1 7 4 7}$ \\
\hline vaccinări copii, gravide şi de necesitate & 307 \\
\hline gravide & $\mathbf{2 6 5}$ \\
\hline lehuze & $\mathbf{5 7}$ \\
\hline tratamente de mică chirurgie şi injectabile mai complexe (infiltrații) & $\mathbf{4 2}$ \\
\hline $\begin{array}{l}\text { eliberare de acte medico-legale (adeverințe, avize epidemiologice, carnete de control medical } \\
\text { periodic, dosare medicale de încadrare, certificate prenupțiale, certificate de deces, etc) }\end{array}$ & $\mathbf{2 1 3 7}$ \\
\hline TOTAL & \\
\hline \hline profilaxie primară 2378 cazuri & $\mathbf{1 3 . 0 6 5}$ \\
\hline profilaxie secundară 2811 cazuri & $\mathbf{1 8 , 2 \%}$ \\
\hline bliberări acte medico-legale & $\mathbf{2 1 , 5 2 \%}$ \\
\hline tratamente de mică chirurgie & $\mathbf{1 6 , 3 6 \%}$ \\
\hline & $\mathbf{4 3 , 6 2 \%}$ \\
\hline & $\mathbf{0 , 3 2 \%}$ \\
\hline
\end{tabular}



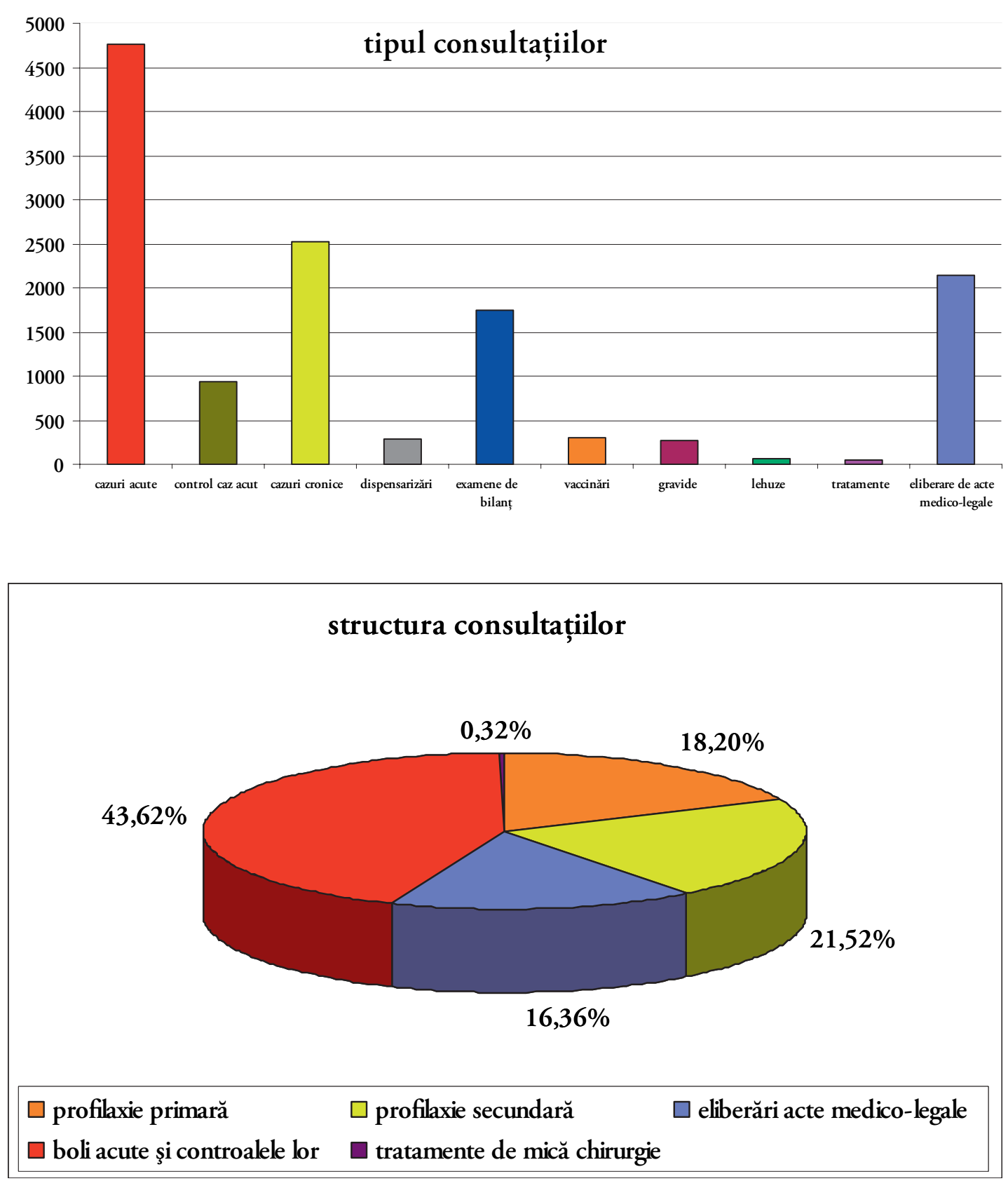

Cazuri noi de boli infecțioase şi parazitare 2007

\begin{tabular}{|l|l|l|l|l|l|l|l|l|l|l|l|l|l|l|l|l|l|}
\hline Denumirea bolii & \multicolumn{10}{|c|}{ Cazuri noi - pe grupe de vârstă în ani } \\
\hline & Total & $\begin{array}{l}1 \\
\text { an }\end{array}$ & & & $\begin{array}{l}2 \\
\text { ani }\end{array}$ & $\begin{array}{l}3 \\
\text { ani }\end{array}$ & $\begin{array}{l}4 \\
\text { ani }\end{array}$ & $\begin{array}{l}5-9 \\
10- \\
14\end{array}$ & $\begin{array}{l}15- \\
19\end{array}$ & $\begin{array}{l}20- \\
24\end{array}$ & $\begin{array}{l}25- \\
34\end{array}$ & $\begin{array}{l}35- \\
44\end{array}$ & $\begin{array}{l}45- \\
54\end{array}$ & $\begin{array}{l}55- \\
64\end{array}$ & $\begin{array}{l}65- \\
74\end{array}$ & $\begin{array}{l}75- \\
84\end{array}$ & $\begin{array}{l}85+ \\
\text { Giardioza } \\
\text { (lambliaza) }\end{array}$ \\
\hline Erizipel & 3 & & & & & & & & & & 1 & & & 1 & 1 & & \\
\hline Trichomoniaza & 1 & & & & & & & & & & 1 & & & & & & \\
\hline Varicela & 24 & 1 & & 1 & 2 & 1 & 9 & 3 & 3 & & 3 & 1 & & & & & \\
\hline Hepatita A & 1 & & & & & & & 1 & & & & & & & & & \\
\hline Dermatofitoze & 48 & 1 & & & & 2 & 4 & 3 & 2 & 7 & 5 & 9 & 5 & 2 & 8 & & \\
\hline Scabia & 2 & & & & & & & & & & & & & 1 & 1 & & \\
\hline
\end{tabular}




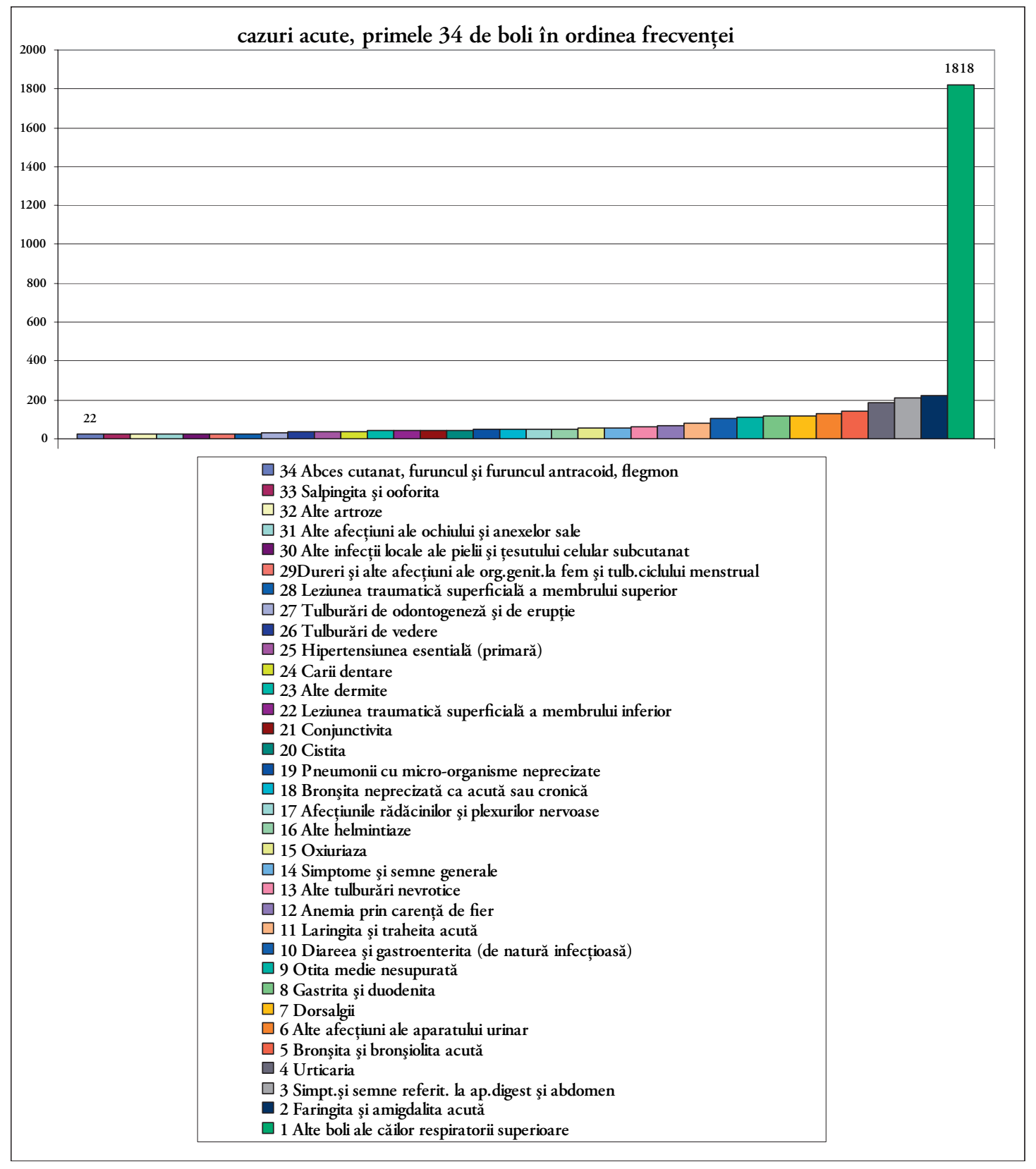

Analizând variația lunară a consultațiilor pe 4 ani, observăm două vârfuri lunare maxime: martie şi octombrie şi două minime: aprilie şi august

\begin{tabular}{|c|c|c|c|c|c|c|c|c|c|c|c|c|c|}
\hline 2007 & ian & feb & mar & apr & mai & iun & iul & aug & sep & oct & nov & dec & total \\
\hline \multicolumn{14}{|c|}{ Consultații din listă proprie şi în afara listei } \\
\hline 2004 & 1186 & 988 & 1363 & 959 & 1152 & 1140 & 1150 & 946 & 1323 & 1452 & 1351 & 1069 & 14079 \\
\hline 2005 & 1268 & 1220 & 1504 & 1169 & 1252 & 1106 & 1082 & 1033 & 1383 & 1415 & 1275 & 1015 & 14722 \\
\hline 2006 & 1145 & 1101 & 1288 & 1183 & 1301 & 1170 & 1061 & 1161 & 1170 & 1337 & 1189 & 969 & 12914 \\
\hline 2007 & 1208 & 1141 & 1304 & 836 & 974 & 1110 & 893 & 1129 & 1257 & 1422 & 1145 & 932 & 13351 \\
\hline media & 1202 & 1113 & 1365 & 1037 & 1170 & 1132 & 1047 & 1067 & 1283 & 1407 & 1240 & 996 & 13767 \\
\hline \begin{tabular}{|l|} 
trimiteri labora- \\
tor şi radiologie
\end{tabular} & 35 & 28 & 33 & 29 & 31 & 31 & 46 & 38 & 29 & 36 & 24 & 19 & 379 \\
\hline $\begin{array}{l}\text { trimiteri spre } \\
\text { ambulator }\end{array}$ & 136 & 105 & 135 & 95 & 153 & 144 & 125 & 121 & 115 & 160 & 105 & 85 & 1477 \\
\hline
\end{tabular}




\begin{tabular}{|l|l|l|l|l|l|l|l|l|l|l|l|l|l|}
\hline $\begin{array}{l}\text { trimiteri pentru } \\
\text { internare }\end{array}$ & 9 & 4 & 3 & 1 & 1 & 5 & 4 & 10 & 5 & 6 & 2 & 3 & 53 \\
\hline total trimiteri & 180 & 137 & 171 & 125 & 185 & 180 & 175 & 169 & 149 & 202 & 131 & 107 & 1909 \\
\hline $\begin{array}{l}\text { scrisori me- } \\
\text { dicale din } \\
\text { ambulator }\end{array}$ & 17 & 8 & 18 & 7 & 9 & 18 & 15 & 18 & 16 & 14 & 19 & 11 & 170 \\
\hline $\begin{array}{l}\text { scrisori medi- } \\
\text { cale din spital }\end{array}$ & 18 & 13 & 16 & 2 & 17 & 11 & 19 & 26 & 16 & 15 & 19 & 10 & 182 \\
\hline $\begin{array}{l}\text { total scrisori } \\
\text { medicale }\end{array}$ & 35 & 21 & 34 & 9 & 26 & 28 & 34 & 44 & 32 & 29 & 38 & 21 & 352 \\
\hline
\end{tabular}
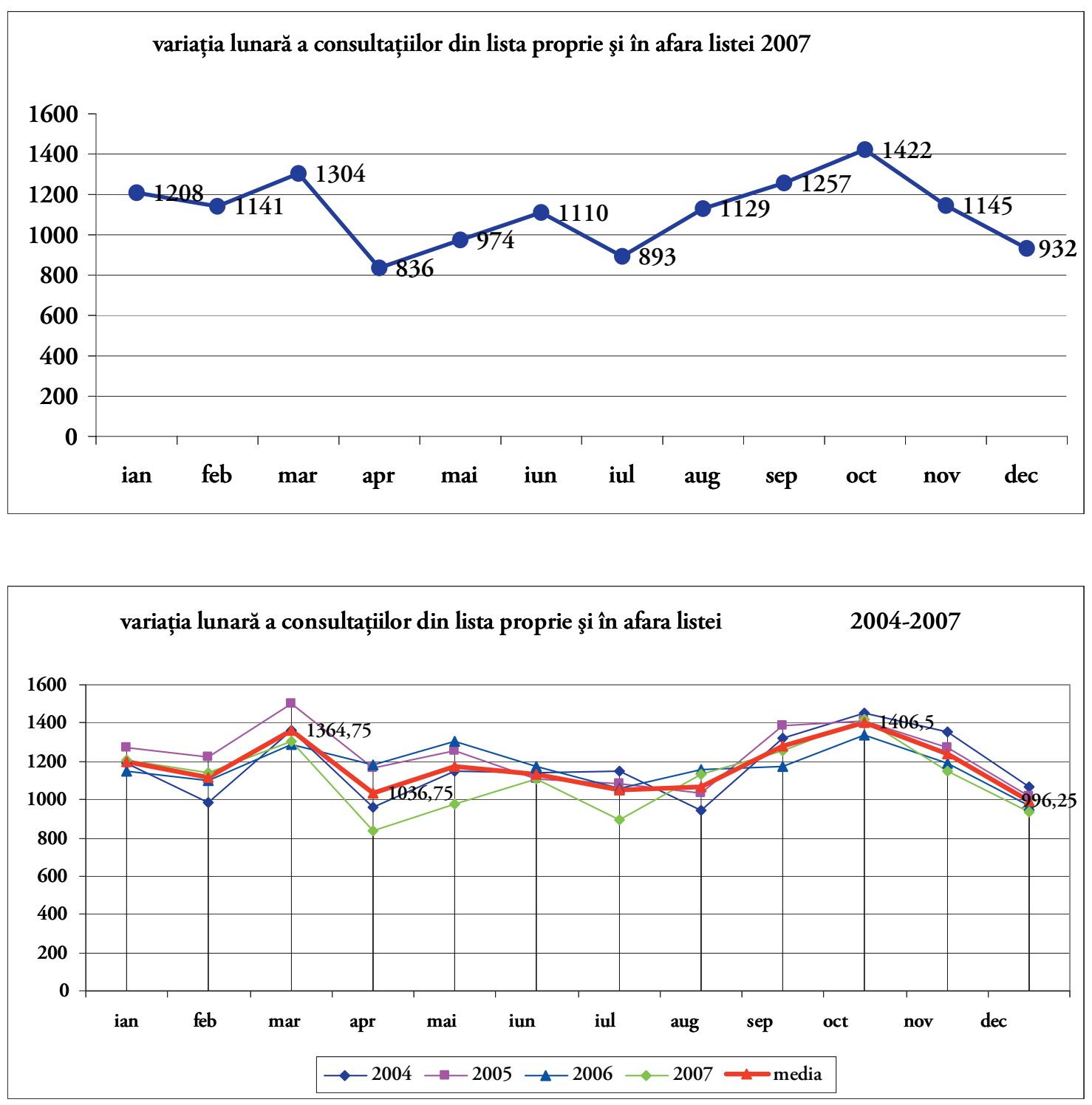

Rețete prescrise la nivelul cabinetului în sistemul de asigurări sociale de sănătate în 2007:

\begin{tabular}{|c|c|c|c|c|c|c|c|c|c|c|c|c|c|}
\hline $\mathbf{2 0 0 7}$ & ian & feb & mar & apr & mai & iun & iul & aug & sep & oct & nov & dec & total \\
\hline gratuite & 189 & 292 & 375 & 197 & 200 & 246 & 196 & 220 & 234 & 362 & 319 & 285 & 3115 \\
\hline compensate & 233 & 250 & 302 & 213 & 298 & 267 & 217 & 323 & 316 & 356 & 342 & 314 & 3431 \\
\hline total & 422 & 542 & 677 & 410 & 498 & 513 & 413 & 543 & 550 & 718 & 661 & 599 & 6546 \\
\hline
\end{tabular}


În urma a 13351 consultații din lista proprie şi din afara listei, au fost prescrise 6546 de rețete compensate sau gratuite în sistemul de asigurări, adică 49\% din consultații, cu mențiunea că unele consultații au fost urmate de mai multe rețete pentru mai multe afecțiuni.

În ceea ce priveşte raportul dintre trimiterile către ambulator şi spital şi scrisorile medicale primite observăm o diferență de 5,42 ori, ceea ce arată deficitul de comunicare între segmentele sistemului sanitar. De subliniat că una din cauzele „eşecului” reformei sanitare din Polonia a fost considerată lipsa de comunicare dintre componentele sistemului sanitar
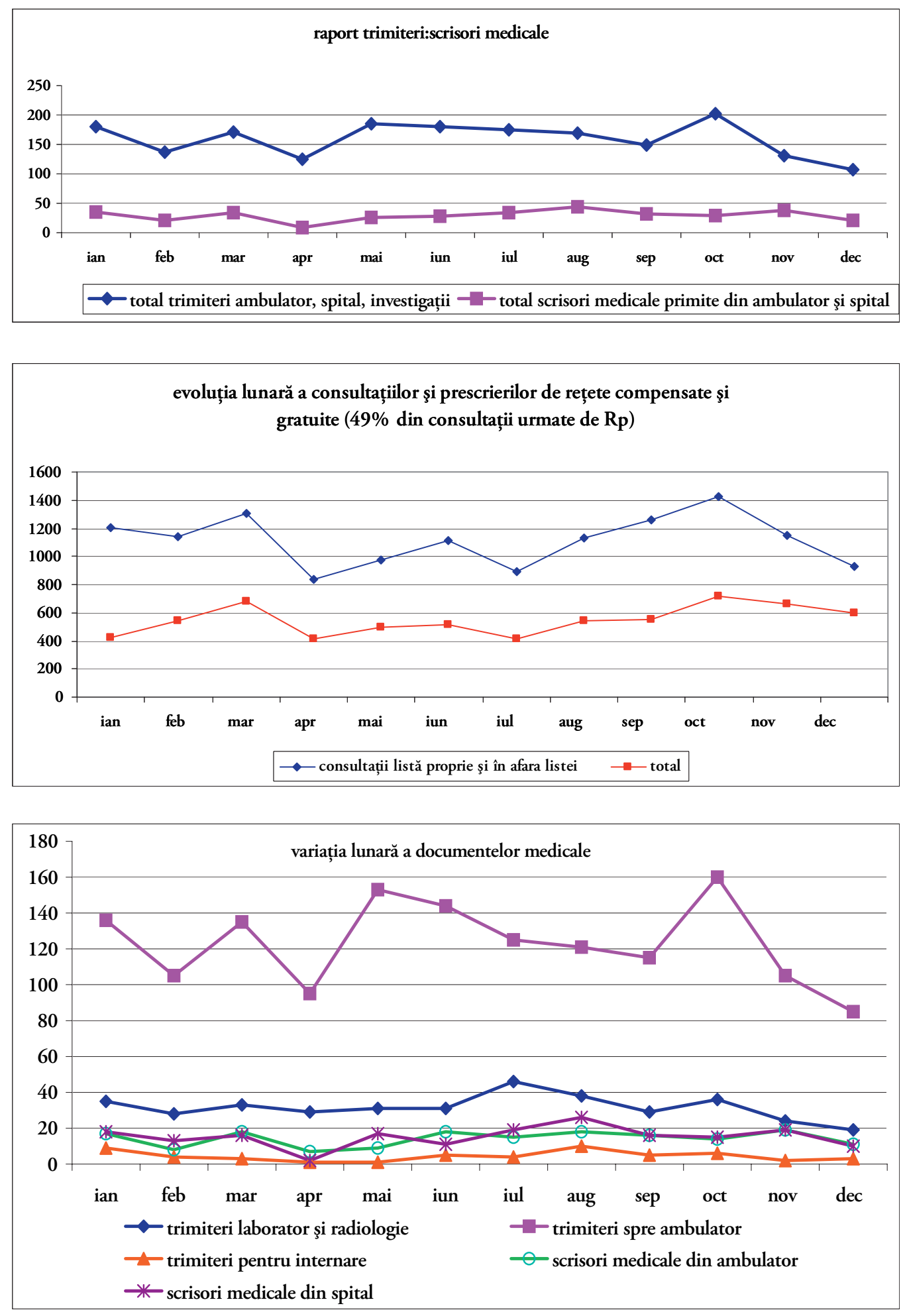


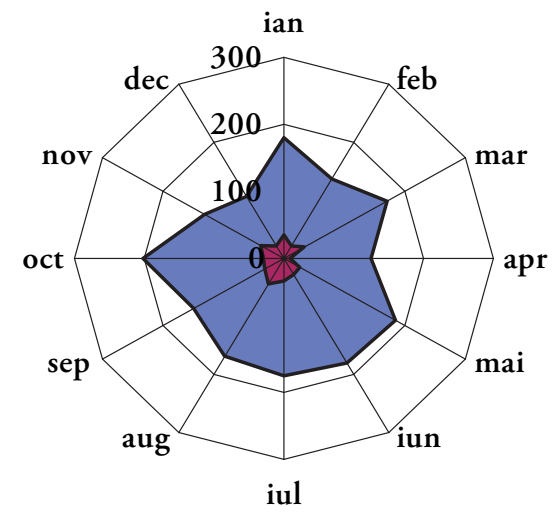

$\square$ total trimiteri ambulator, spital, investigații

total scrisori medicale primite din ambulator şi spital

\section{Concluzii}

1. există diferențe între activitatea reală a unui cabinet de medicina familiei şi statisticile oficiale ale CNAS, care cuprind doar servicii plătite de aceasta

2. cazurile acute reprezintă un procent mult mai mare din activitatea medicului de familie decât activitatea profilactică

3. eliberarea de acte medicale ocupă nejustificat de mult timp (16,36\%), mai ales când nu reprezintă urmarea unui act medical imediat, ceea ce demonstrează excesul birocratic cel puțin la nivelul încadrărilor în colectivități, o fişă electronică sau un card cu informații în posesia asiguraților economisind nu doar timpul medicului, cât mai ales al acestora

4. demonstrarea necesității unei platforme soft pentru evidența primară a cabinetelor de medicina familiei, care să permită prelucrarea statistică pentru un număr de indicatori mai mare, necesari pentru studii epidemiologice şi de sănătate publică

5. comunicarea între părțile sistemului sanitar nu este satisfăcătoare, un sistem informatic unic cu adevărat integrat putând să amelioreze situația

\section{Bibliografie}

1. Askew DA; Glasziou PP; Del Mar CB: Research output of Australian general practice: a comparison with medicine, surgery and public health, Med J Aust. 2001; 175(2):77-80 (ISSN: 0025-729X), Centre for General Practice, University of Queensland, Herston. d.askew@sph.uq.edu.au

2. Raport privind activitatea Casei Naționale de Asigurări de Sănătate în anul 2006, www.casan.ro/pdf/ Prezentare_Raport_2006v1.ppt

3. Raport privind activitatea Casei Naționale de Asigurări de Sănătate pe anul 2007, www.casan.ro/ RAPCNAS_2007.pdf

4. Tarantino L: Finanțare pentru sănătate. Studiu privind medicii de familie, furnizorii de servicii de sănătate şi distribuitorii de produse medicale, septembrie 2007, studiu-privind-medicii-de-familie-furnizorii-deservicii-de-sanatate-si-distribuitorii-de-produse-medicale2856[1]ppt 